\title{
Library Instruction to 2000 Freshmen
}

By VERNA V. MELUM

$\mathrm{C}$ AN FORMAL INSTRUCTION in the use of libraries be given to all college freshmen in these days of steadily increasing enrollments? The staff of Swen Franklin Parson Library at Northern Illinois University says it can. Such a program was started in 1943, when there were four sections of freshman English composition; it has been continued up to the point of fifty-four sections in the fall of 1959, and continued with sixty sections during the current fall term.

The first two essentials for Northern's program are the cooperation of the English Department and released library staff time. The English Department accepts as a definite part of its freshman composition course one week of library instruction given by a librarian.

This program was begun by a member of the library staff after World War II when there was an influx of ex-service men to our college. When the library science area was started, library instruction to freshmen was given by members of this department. The reference librarian taught classes occasionally when there were conflicts of schedules, and the assistant librarian took over the program one year. The next year the library science area resumed this responsibility and continued to carry it for several years.

As the number of English sections continued to increase and the importance of the program continued to be evident, a new position, teacher of library instruction and readers' adviser, was added in the fall of 1957. Two years later the position of assistant reference librarian, readers' adviser, and teacher of library instruction was added. The combination of teachtng and advising has proved to be a logical and efficient one, for the students who have had this instruction ask help
Miss Melum is Teacher of Library Administration and Readers' Adviser, Northern Illinois University, DeKalb.

more readily from staff members whom they already know.

\section{Duties OF TEACHERS}

The teacher of library instruction and readers' adviser gives full time to the teaching program the first semester, or at least until the Christmas holidays. She schedules, plans, and organizes the work, teaches two or three hours a day, spends as much time as possible at the card cata$\log$ or in the reference room to help the freshmen with the problems assigned, and corrects and grades these problems. The assistant reference librarian teaches some of the classes and assists at the advisory desk.

During the second semester, when there are only a few new classes of freshman English composition, the first adviser teaches them all, works up new materials for teaching, shares the duties of readers' advising with the reference assistant, and helps out at the circulation and reference desks. She has also taught a library science course when the library science area has been short-staffed.

\section{Schedule}

The whole-hearted cooperation of the English Department is further evident in their acceptance of the schedule made out by the librarians. This factor is important in order that the teaching librarians may fit the classes, including late afternoon and evening classes, into logical working loads each week and also carry out their other commitments. The 
English teachers are notified at the beginning of the semester of the dates and the rooms for library instruction for their sections. All classes are taught at their regularly scheduled class hours. The librarian goes to the regular classroom if she is teaching only one section, but for the past two years the problem of an ever-increasing number of sections has been met by scheduling two sections together whenever a room anywhere on campus large enough to accommodate up to seventy students is available. Here the cooperation of the registrar has been enlisted. The instruction is scheduled for as early in the school year as possible, but it necessarily extends over most of the first semester.

\section{HANDBOOK}

Mimeographed lesson materials were replaced in the fall of 1958 by a verityped handbook. The first edition contained six sections: I. Staff, Areas and Floor Plans of the Library, II. Locating and Obtaining Books and Other Materials, III. Loan Privileges, IV. The Card Catalog, V. Periodical Indexes, and VI. Reference Books. In the second edition the local orientation material of the first three sections was condensed into one page. This same material was also published separately on brightly-colored single sheets, with the floor plans on the back, for distribution to all students at registration.

The handbook is sold to students at fifty cents a copy. Since it was produced on campus by the Duplicating Service and the Industrial Arts Department, the cost is well below this figure, but it has seemed desirable to charge an amount which recognizes both the labor involved and the value of the material to the student. The Wilson pamphlet, "How to Use the Readers' Guide to Periodical Literature . . . and other Indexes," is included with each handbook. Mimeographed worksheets designed to emphasize the points the students are expected to master, and therefore to serve as a method of study, are given out with the handbooks.

\section{Problems}

The handbook and its worksheets do not give the students actual practice in the use of the library tools. Therefore problems are assigned also. The types and the forms of these problems have, of course, gone through many stages of development. Our present plan for problems on the card catalog and on periodical indexes is meeting the following criteria satisfactorily: (1) to provide actual library practice for each student, (2) to provide enough different problems to avoid excessive wear on the library tools and to avoid students' copying from each other, (3) to provide for quick but definite checking and grading.

The plan consists of 125 different sets of problems, set up on $5^{\prime \prime} \times 8^{\prime \prime}$ mimeographed form cards, white cards for the clues, green cards for the keys. The clues for the students are typed in red on the white mimeographed cards; the students copy onto mimeographed form sheets provided them. (See forms below.) The instruction, "Copy everything in red," is easily followed and does not seem to be confused with the fact that only subjects are in red on catalog cards. (The notation "in red" is added after subject headings.) Ten or twelve minutes of class time are required for this copying. Though this is a sacrifice of some time that could well be used for explanations, the plan saves so much clerical time that it is well worth while. Every student in a class group gets a different set of problems; the cards are collected and used again and again with other class groups. Another advantage of the plan is that problems can be changed or added at any time. Fifty sets were sufficient to begin with; 125 sets have been completed. A few sets have been marked "Advanced" and numbered in the 200's; these are harder problems intended for 
students who already have a knowledge of the fundamentals.

Definite criteria have been set up for making out the problems in order that certain points will be included in each set:

\section{Card Catalog Problems}

1. POINT OF EMPHASIS: AN $A U$ THOR OR A TITLE. A personal author or a title to look up publisher and date given as further clues with an author's name.

2. POINT OF EMPHASIS: A SUB$J E C T$. Publisher and date given as further clues. Author and title avoided as clues in order to force the student to look up a subject.

3. POINT OF EMPHASIS: AN ORGANIZATION AS AN AUTHOR. Title given as clue.

4. POINT OF EMPHASIS: A CROSS REFERENCE. First line of "See" reference given; student to complete this reference. Publisher and date of a book under the subject referred to given as clues. Authors and titles avoided as clues in order that the student will be forced to follow through with a cross reference.

On the line, "One other item of information," such an item as number of pages, subtitle, series, or bibliography is called for, a variety of these being included in each set. These items are considered more advanced work and therefore are not required for an average or satisfactory grade. At least one call number consisting of more than two lines, often one including a special location, is included in each set.

The problems are made out on form sheets with complete information for the keys. The items which are to be given to the students as clues are checked with a colored pencil. The typist then can make out both cards, the clues cards and the keys cards. In making out the problems care has to be taken that only one card in the catalog and only one entry in an index has the clues given.
Form for Catalog Problems

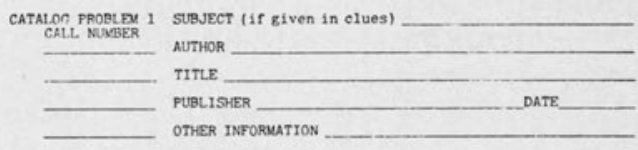

Periodical Indexes Problems

1. READERS' GUIDE OR EDUCATION INDEX

2. ONE OF THE SPECIAL SUBJECT FIELD INDEXES LISTED IN THE HANDBOOK

For each of these problems the same items are given as clues: name of index; subject; title of article; year.

\section{Form for Periodical Index Problems}

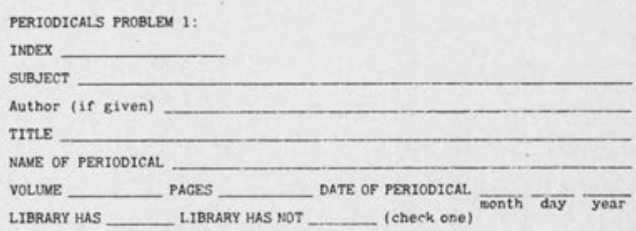

In addition to four specific card catalog problems and two periodical indexes problems, forms are provided for selecting random examples in other indexes and in reference tools. This plan does not meet the criteria of discouraging copying and of providing quick but definite checking, but still it seems to fulfill its major purpose of getting the students to use the specified tools without causing the wear and tear on the books which specific problems entail. Many students have expressed interest and surprise to learn that these reference books and tools exist. If the teacher were to check every answer, this plan would be too laborious; she merely scans most of the problems to see whether the answers are logical ones, spot-checking occasionally, especially in cases where she questions the validity of the answers. She calls in students who have handed in identical problems and assigns them further work, thus discouraging copying.

COLLEGE AND RESEARCH LIBRARIES 
FORMS FOR SELECTED REFERENCE TOOLS

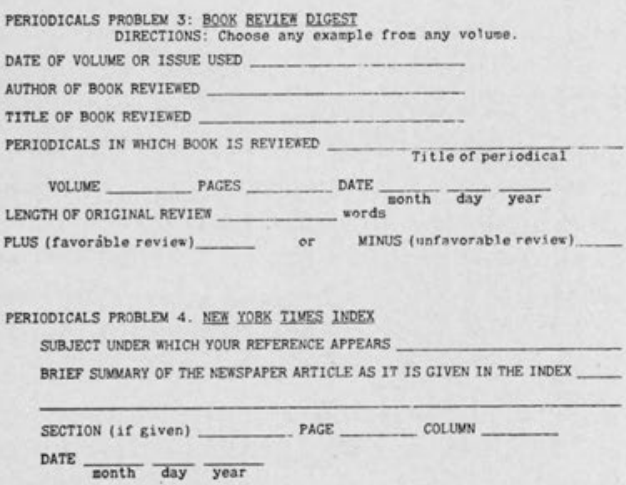

REFERENCE PROBLOU 7: NORLD ALUANAC Or WFORMATJON ELEASE ALVANAC (required Check the book used

Place of publication Choose one itex in the index: Kain Heading Subheading (if any, Give one fact given on this page about this ites

REFERENCE PROBLDN 9: STATESUAN'S YEABBOQK (required)

Place of publication Publisher
Choose a country (Look up this country in the index) Date
(Name of country)

Give page on which inforation on this country begins

Choose one heading or topic under this country

(Heading)

Give one fact under this heading

Is there an index in this book? Yes __ No __ (Check one)

\section{REFERENCE PROBLDU 12. COLUNAIS LIPPINCOTI GAZETTEEB OF THE KOBLD} WFBSTER'S GEOCBAFHICAL, DICTIONABX (one required)

CHECK above the book chosen.

Choose one itea

Identify this ites as to zeorraphical type (eity, wountain, otc.) and location

Give one other fact about this iten

Give page on which inforeation is found

REFEREACE PROBLEX 1. (any one of the following - one required)

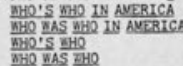

CHECK above the book chosen.

place of publication

Publisher

Date

Choose one person about whom information is given

Give date of birth of this person

Give one position or office this person has held

Give page on which the above information about this person is given

RERERENCE PROBLEX 2. CURRENT BTOGRAPHY (required)

Place of publication Publisher

Choose one person about whow information is given Date

Give page on which the article about his begins

Give date of birth of this person.

Give oceupation of this person

Give one other item of inforation about this person

Give one bibliographic reference
In addition to the above forms, blanks are also provided for the following:

PERIODICAL INDEX OF YOUR OWN Choice Not Used in Your Other Problems But Listed In The HANDBOOK

Dictionary OF AMERICAN BIOGRAPHY Or DICTIONARY OF NATIONAL BIOGRAPHY

Statistical Abstract of the United States

BARTLETT'S FAMILIAR QUOTATIONS OR STEvenson's HoMe BoOK OF QUOTATIONS

\section{Granger's Index to Poetry}

A sheet of directions is attached to the problem forms, and blanks are provided for the name of the student, the name of the English teacher, and the hour of the class meeting.

\section{TEST}

A multiple-choice test of from fifty to sixty questions is given at the close of the unit, thirty minutes being allowed for this test. Machine-scored answer sheets are used. The Office of Testing Services has done item analyses on the tests to determine which items discriminate well and to scale the items in order of difficulty to some extent. However, the questions are grouped, first, by subject matter; second, by order of difficulty within the group. Some easy items which all students should be able to answer are included as morale builders. Because this testing is for mastery, the test is comprehensive, covering all areas.

\section{Clerical Help}

Even though Northern's plan eliminates preparation of problems for each individual student, considerable clerical work is involved in the typing of mimeograph stencils for forms and tests and the typing of the cards (both clues and keys), as well as such routines as counting out materials and recording grades. For this work a student assistant is employed eight or ten hours a week. 


\section{Grading}

Because the unit of library instruction extends over a full week and because grades are one method of motivation, both the problems and the test are graded and these grades averaged for a final grade on the unit. Two methods of grading have been used. The first method is to grade both the problems and the test with the usual letter grades of "A, B, C, D, F" and to count the problems one-third and the test two-thirds for the unit grade.

The second method is to use only Satisfactory or Unsatisfactory for both the problems and the final grade. This seems decidedly preferable for the problems for several reasons: the students are encouraged to get as much help as they need in order to get their problems correct; the random examples selected by students cannot be checked carefully enough to justify specific grades; the emphasis for the unit of instruction is on the skills learned for future use rather than on an immediate grade. This method also seems preferable for the final grade because the English teachers have reported that the library instruction grade often does not correlate with a student's other grades in the English course and therefore it is difficult to know how much weight to attach to it. Two additional reportings are made in order to encourage students to do their best work, however; first, a letter grade is reported for the test so that the student may know the degree of proficiency he attained; second, an "S plus" is reported for students who have almost perfect work on the problems and " $\mathrm{A}$ " on the test.

\section{Questions Settled and Unsettled}

Can the work be motivated sufficiently without giving grades? Is the test necessary? Is it advantageous and practical to use a specific topic for all the problems to be done by one student? These matters have been given consideration from time to time, and are currently being discussed in several conferences with a committee of faculty members of the English Department.

If lectures only were given, grading would be eliminated. But the questions the students ask and the errors they make in both the problems and the test show that lectures do not produce sufficient mastery; practice is needed. Furthermore, the problems have to be checked to insure their being done individually, and a test is in itself both a learning device and a motivating force. It therefore seems highly desirable to continue specific assignments and testing as long as such a program can possibly be managed. A disadvantage of the testing is that the student does not find out what points he missed. It is not feasible to give him this information for two reasons: (1) the librarian does not meet the class again after the test has been given; (2) the same test is used with many groups. This objection is being met somewhat by giving a few warm-up exercises and discussing them before the test is given.

\section{Problems on One Topic}

The assignment to look up entirely unrelated items can be motivated only by stimulating interest in learning that such sources are available. One has to start somewhere, and interest in unrelated quiz-type facts is still alive. Yet motivation would be higher and the value to the student greater if he uses an individually assigned topic for all the problems, or at least for all the reference problems.

The plan of having all of the specific problems on the card catalog and the periodical indexes in a set on one topic has been tried but has been abandoned because of the time required to meet both this requirement and the criteria designed to cover certain specific points which we wish to teach.

Some experimenting has been done in a few sections this semester with the plan 
of having each student select a topic to use for all of the problems not specifically assigned from the cards. $\mathrm{He}$ is to try to find this topic in each of the assigned references. One teacher assigned the general topic of "gems," each student to select one precious stone as his specific topic. Two difficulties encountered in trying to use the one-topic assignment are: (1) much labor is involved in selecting topics which will be found in the majority of the books assigned; (2) topics do not apply to the biographical sources. (Some have occupational indexes in them, but this is not the most common way of using these tools. If the student were reading on his topic, he would come across names important in the field, but since this work is only bibliographic, he would not have this information.) It can be suggested to the student however, that he might wish to use a single topic for as many of the problems as he can. This idea would make the library instruction assignments more purposeful to some students.

\section{Ultimate Goals}

The teaching of any skill subject involves the hazard of letting the larger purposes become obscured by the details. Does this program of library instruction teach more than the use of library tools? Does it teach the students how to tackle a new subject? Does it inspire students to make their own further explorations in the wonderful world of books and other printed materials? Can the teacher who teaches the same content according to the same plan, week after week for almost an entire semester, keep above boredom himself and lift his students to see beyond the commas and the dashes, the catalogs and the indexes? Are his students gaining intellectual curiosity? Herein lie real challenges to the teacher.

This unit presents to the college freshman a handbook of material to be covered in one week. For many it is an entirely new subject. How should the student ap- proach it? Does he note the terminology? Does he know how to select the most important items for mastery? He needs guidance in doing so. If he has used some of the tools before, he needs guidance in noting more advanced points; he should not be given the opportunity to become bored because he thinks he already knows it all. Does he pay attention to accuracy and detail, or is he a careless worker? Does he know the pitfalls and the guides in objective tests? The assignments call for accuracy in detail and care in following directions. The multiplechoice test is an exercise in discriminatory thinking as well as a test of knowledge of how to use the library. Library instruction can help careless students to improve their methods of study.

Occasional remarks from even a few students that they will use the library more now that they know where to start and that they are glad to have their careless errors pointed out to them, help the teacher to see each new group as a new opportunity to teach the silent influence of books.

\section{Planning for the Future}

The library staff of Northern Illinois University recognizes that the ideal procedure is to give each individual student help on his particular problem as the need arises. But with an enrollment. of several thousand students this is not always possible. Therefore this library staff considers its program of formal teaching of classes for several periods a strong one and plans to continue it as long as such a plan is practicable. But it is also considering other ways in which library instruction might be given when the enrollment soars far beyond the sixty sections of freshman English expected in 1960.

Should library instruction always be given in English classes? Are not other departments, such as Social Science and Speech, interested in having their students learn how to use the library? Cer- 
tainly the answer to this question is in the affirmative. But in most colleges English is the only course which enrolls all or most of the new students. If library instruction is offered in some other department, will enough of the students be reached? Can plans be made for reaching those who are not enrolled in that particular department?

When it is no longer feasible for the readers' advisers to go to the classrooms, they might plan units of instruction which could be presented by the teachers, the advisers staying in the library to work with students as they do the problems assigned.

But a far better solution would be presentation of library instruction over closed-circuit television. When the campus of NIU becomes equipped for teaching by this method, library instruction promises to be among the first units so taught. The readers' advisers would present the programs to many classes or other large units at once; classroom teachers could follow up with handing out problems and giving tests.

Whatever the method, the readers' advisers at NIU expect to continue planning and organizing library instruction for as large a segement of the student body as possible, for they believe that library instruction can best be given by librarians.

\section{New Zealand Library Resources}

Andrew D. Osborn, formerly assistant librarian at Harvard University, and now librarian at the University of Sydney, Australia, is the author of New Zealand Library Resources (Wellington, New Zealand Library Association, 1960, 70 p., 5s to members, 7s.6d. to non-members, NZ currency, plus postage). This is a report of a survey for the New Zealand Libraray Association under the auspices of the Carnegie Corporation of New York. Dr. Osborn covers in this report problems dealing with public, school, special academic libraries. Starting from the Munn-Barr report of 1934, Osborn traces the development of library service on the several levels. "As a group the public libraries are easily the brightest spot in the New Zealand Library picture," writes Osborn. The Auckland Public Library, for example, has among its holdings several of the best collections. Similar collections exist in Wellington, Christchurch and Dunedin. In respect to university libraries, Osborn observed, "In each of the past decades the plight of the university libraries has been a matter of concern to professors, students, investigating bodies and others. Document after document has hammered away at the inadequacies for teaching and research libraries, the lack of financial support and the overall failure to look on the library as the heart of the university." Dr. Osborn is categorical in his recommendations that bold steps must be taken to strengthen resources and facilities if the university libraries of the country are to serve the constitiuent groups depending upon them. $\mathrm{He}$ is also direct in his support of the need of a strong National Library. "Establishment of a National Library is a matter that is worth doing, and worth doing well." In order to accomplish this, prompt and decisive actions are essential. The National Library may be a useful instrument in the development of the library resources of New Zealand, described by Dr. Osborn as "slender." His program includes the acquition of materials of various kinds, for all groups of readers and researchers, in all subject fields, for all types of libraries. 